\title{
Effects of Long and Short-Term Progestagen Treatments Combined with PMSG on Oestrus Synchronization and Fertility in Awassi Ewes during the Breeding Season
}

\author{
B. USTUNER ${ }^{1}$, U. GUNAY ${ }^{1}$, Z. NUR, ${ }^{1}$ H. USTUNER ${ }^{2}$ \\ ${ }^{1}$ Department of Reproduction and Artificial Insemination, ${ }^{2}$ Department of Animal Science, Faculty of Veterinary \\ Medicine, Uludag University, Bursa, Turkey \\ Received March 12, 2007 \\ Accepted July 9, 2007
}

\begin{abstract}
Ustuner B., U. Gunay, Z. Nur, H. Ustuner: Effects of Long and Short-Term Progestagen Treatments Combined with PMSG on Oestrus Synchronization and Fertility in Awassi Ewes During the Breeding Season. Acta Vet. Brno 2007, 76: 391-397.

Synchronization of oestrus has been used to increase reproductive efficiency in most animals, including ewes. The aim of the present study was to compare the effect of the length of a progestagen treatment ( $12 \mathrm{~d}$ vs. $6 \mathrm{~d}$ ) on synchronization efficiency (oestrus response, time to onset of oestrus and duration of oestrus) and fertility rate using fluorogestone acetate (FGA) progestagen sponge treatment with pregnant mare serum gonadotropin (PMSG) administration applied at different times of sponge removal. Ewes $(n=68)$ were divided into two groups; long term $(\mathrm{LT}, \mathrm{n}=33)$ and short term $(\mathrm{ST}, \mathrm{n}=35)$ groups treated with FGA progestagen sponges. At the end of intravaginal sponge treatment period the animals of each group were divided into the 3 subgroups in relation to time of PMSG (300 IU) treatment. PMSG treatment was applied $24 \mathrm{~h}$ before sponge removal, at sponge removal and $24 \mathrm{~h}$ after sponge removal for LT1 and ST1, LT2 and ST2, and LT3 and ST3, respectively. Each ewe was inseminated intra-cervically twice with skim cow milk-diluted semen $\left(1000 \times 10^{6}\right.$ motile cells $\left./ \mathrm{ml}\right) 40 \mathrm{~h}$ and $60 \mathrm{~h}$ after sponge removal. Non-return rates (NRR-30) were monitored from 12 day after sponge removal to 30 day with the aid of teaser rams. Onsets of oestrus response and oestrus cessation were significantly different $(P<0.05)$ between the ST and LT treatment groups. Synchronization of oestrus was tighter in LT than ST group. Except for oestrus cessation, other indicators studied were not different in the ST subgroups. In the ST subgroups the oestrus cessation of the ST1 $(88.7 \pm 15.4 \mathrm{~h})$ was the shortest and differed from ST3 $(120.0 \pm 14.2 \mathrm{~h})(P<0.05)$. No statistical difference was observed among all studied indicators for LT groups according to application time of PMSG $(P>0.05)$. The NRR-30 and lambing rate of the ST and LT after timed AI were $35.7 \%$ and $31.0 \%$ and $32.1 \%$ and $28.6 \%$, respectively $(P>0.05)$.
\end{abstract}

Sheep, oestrus synchronization, artificial insemination, fertility

Progestagen analogues have been widely used in small ruminants to induce and synchronize oestrus (Baril et al. 1993; Romano 1996; Greyling et al. 1997; Vinoles et al. 1999a; Simonetti et al. 2000; Vinoles et al. 2001; Drion et al. 2001; Ataman et al. 2005; Zeleke et al. 2005; Dogan and Nur 2006; Emsen and Yaprak 2006). Recent studies (Vinoles et al. 2001; Ataman et al. 2005; Zeleke et al. 2005) have focused on the duration of the progestagen-based synchrony treatments. Intra-vaginal devices containing different types of progestagens, maintained during $6-14$ days associated with or without PMSG or PMSG and ProstaglandinF $2 \alpha\left(\mathrm{PGF}_{2} \alpha\right)$ combinations have been used (Eppleston et al. 1991; Roy et al. 1999; Vinoles et al. 2001; Ungerfeld and Rubianes 2002; Ataman et al. 2005; Zeleke et al. 2005). As a result of the oestrus synchronization protocols, a high percentage of ewes show oestrus, but fertility is lower than in ewes showing natural oestrus. This low fertility rate has been attributed to changes in the hormonal milieu that results in an asynchrony between oestrus and ovulation (Scaramuzzi et al. 1988), with a subsequent alteration in sperm transport (Pearce and Robinson 1985). 
Recently, Ungerfeld and Rubianes (1999b) found that short-term treatment (5 - 6 d) with different progestagen devices during the non-breeding season was as effective as long-term treatment to induce oestrus and the subsequent fertility. During the breeding season and with natural mating, Vinoles et al. (2001) obtained higher pregnancy rate after a shortterm treatment (six days of medroxyprogesterone acetate (MAP) sponges, 87\%) compared to the traditional 12-day treatment either with $(67 \%)$ or without $(63 \%)$ an equine chorionic gonadotropin $(\mathrm{eCG})$ dose at the time of sponge withdrawal. Progestagen 5-day treatment was used in combination with $\mathrm{PGF}_{2} \alpha$ to improve oestrus synchronization with good results (Vinoles et al. 2001; Menchaca and Rubianes 2004) but the potential benefit of a shortterm treatment alone in combination with fixed time artificial insemination has not yet been evaluated.

Oestrus response and fertility vary greatly when intra-vaginal sponge is applied, depending on species, breed, co-treatment, management, breeding season and mating system (Romano 1996; Greyling et al. 1997; Simonetti et al. 2000; Ungerfeld and Rubianes 2002; Menchaca and Rubianes 2004; Dogan and Nur 2006; Emsen and Yaprak 2006). Also the successfulness of progestagen treatment is affected by the body condition and physiological state of ewes, breeding or artificial insemination (AI) time (Baril et al. 1993; Evans et al. 2004; Menchaca and Rubianes 2004).

Various studies (Eppleston et al. 1991; Menchaca and Rubianes 2004; Zeleke et al. 2005) have evaluated different PMSG dose levels, injection time and alternative types of gonadotropins; however, the effect of PMSG treatment on fertility is still controversial (Baril et al. 1993; Drion et al. 2001).

The aim of this study was to compare the effect of the length of a progestagen treatment ( $12 \mathrm{~d}$ vs. $6 \mathrm{~d}$ ) on synchronization efficiency (oestrus response, time to the onset of oestrus and duration of oestrus) and the fertility rate using FGA treatment with PMSG administration applied at different times of sponge removal.

\section{Materials and Methods}

Animals and experimental protocol

The experiment was carried out at the Uludag University Veterinary Faculty Farm, (lat $40.1833^{\circ}$, long $29.0667^{\circ}$, alt 100 metres) in Northwestern Anatolia during the breeding season (September) under natural lighting. In this study, 68 clinically healthy fat-tailed Awassi ewes ( 2 to 5 year old), 3 fertile Awassi rams for semen collection and 5 teaser rams for oestrus detection were used. These teaser rams were used rotationally (changed daily). Ewes were kept away from the rams to prevent voluntary mating. In the meantime, a teaser ram was introduced to the flock for a short time $(1 \mathrm{~h})$ on each occasion (once or twice weekly) to determine the presence of oestrus cyclicality in season. Sixty-eight ewes had given birth in previous February. Their milking period terminated in August and these animals had never been treated with PMSG in the past. Body weights and condition scores of these animals were recorded prior the experiment. Ewes weighing between 50 to $85 \mathrm{~kg}$ with good body conditions (BCS: 3 to 4.0 ) were used. Lengths of progesterone administration (long term; 12d vs. short term; 6d) and time of PMSG treatment in relation to progesterone removal were studied. Ewes $(n=68)$ were divided into two groups; long-term (LT: $12 \mathrm{~d}, \mathrm{n}=33)$ and short-term (ST: $6 \mathrm{~d}, \mathrm{n}=35$ ) groups treated with $30 \mathrm{mg}$ FGA progestagen sponges (Syncro-Part ${ }^{\mathbb{R}}$, Ceva Sante Animale, France). Ewes of each group were divided into 3 subgroups according to the PMSG (Syncro-Part ${ }^{\mathbb{R}}$ PMSG-300 IU, Ceva Sante Animale, France) treatment time. PMSG treatment was applied $24 \mathrm{~h}$ before sponge removal, at sponge removal and $24 \mathrm{~h}$ after sponge removal for LT1 and ST1, LT2 and ST2, and LT3 and ST3, respectively.

Observation of oestrus signs

Ewes were monitored every $6 \mathrm{~h}$ for $1 \mathrm{~h}$ starting from $12 \mathrm{~h}$ to $140 \mathrm{~h}$ after sponge removal for both the signs of oestrus behaviour and their durations with the aid of teaser rams. Ewes were considered in oestrus when they allowed the male to mount. Oestrus duration was defined as the time elapsed between the first and last accepted mount within the same oestrus period. Oestrus cessation was defined as the time elapsed between sponge removal and last accepted mount within the same oestrus period.

Three rams with previously proven fertility were used for semen collection with the aid of artificial vagina in the presence of a ewe in oestrus. Each ejaculate was immediately evaluated for volume, wave activity, motility and concentration. Only ejaculates with a volume of more than $0.5 \mathrm{ml}$, good wave activity $(+++)$ and motility $70 \%$ and minimum $2.5 \times 10^{9}$ sperm cells $/ \mathrm{ml}$ were used. The ejaculates from each ram were mixed, pooled and maintained at $30{ }^{\circ} \mathrm{C}$. The semen was diluted to a sperm concentration of $1000 \times 10^{6}$ motile sperm cells $/ \mathrm{ml} \mathrm{after}$ being counted with the aid of a haemocytometer. A one-step dilution was performed with the addition of sterilized 
cow skim milk containing $1000 \mathrm{IU}$ sodium G penicillin and $1000 \mu \mathrm{g} / \mathrm{ml}$ dihydrostreptomycine sulphate. Each ewe (whether in oestrus or not) was inseminated intra-cervically twice at 40 and $60 \mathrm{~h}$ after sponge removal, with a $0.25 \mathrm{ml}$ straw containing 250 million spermatozoa.

Non-return rate (NRR-30) and lambing rate

NRR-30 was determined (starting from day 12 after sponge removal to day 30) by observations (twice daily) with the aid of an accompanying teaser ram. Lambing rates (percentage of ewes lambing) were recorded following the $150 \pm 5$ days of inseminations.

\section{Statistical Analyses}

In this study, the time to the onset of oestrus, oestrus response at $18 \pm 6 \mathrm{~h}$ and $140 \mathrm{~h}$, duration of oestrus, NRR30 , and lambing rate were evaluated. The onset of oestrus and duration of induced oestrus periods were subjected to analyses of variance (one-way ANOVA) and the differences among means were tested for significance by the Fisher's PLSD. Oestrus responses at $18 \pm 6 \mathrm{~h}$ and $140 \mathrm{~h}, \mathrm{NRR}-30$ and lambing rates were analyzed using the Fisher's Exact Test. The 95\% significance level was noted as significant. All statistical analyses were carried out using the computer program Instat (Graph Pad Instat ${ }^{\mathrm{tm}}$ ).

\section{Results}

The results in terms of oestrus response for the first $18 \pm 6 \mathrm{~h}$ and within $140 \mathrm{~h}$, time to the onset, duration and cessation of the induced oestrus, are set out in Table 1. NNR-30 and lambing rates are set out in Table 2 . Until $140 \mathrm{~h}$ after sponge withdrawal, a higher number of ewes in LT groups showed oestrus than in the ST groups.

Table 1.Oestrous response, time interval to onset of oestrus, duration and cessation of oestrus in ewes treated with 6 or 12-day intravaginal FGA sponge combined with PMSG

\begin{tabular}{|c|c|c|c|c|c|c|c|}
\hline \multicolumn{2}{|r|}{ Treatments } & \multicolumn{3}{|c|}{ Oestrus Response (\%) } & \multicolumn{2}{|r|}{ Oestrus } & \multirow[b]{2}{*}{ Cessation (h) } \\
\hline & PMSG & $\mathrm{N}$ & $18 \pm 6 \mathrm{~h}$ & Within $140 \mathrm{~h}$ & Onset (h) & Duration (h) & \\
\hline \multirow{4}{*}{ 芯 } & ST1 & 12 & $8 / 4(33.3)^{\mathrm{ac}}$ & $3 / 9(75.0)^{\mathrm{a}}$ & $62.0 \pm 16.8^{\mathrm{ac}}$ & $32.68 \pm 2.8^{\mathrm{a}}$ & $88.7 \pm 15.4^{\text {bce }}$ \\
\hline & ST2 & 12 & $11 / 1(8.3)^{\mathrm{ac}}$ & $2 / 10(83.3)^{\mathrm{a}}$ & $70.8 \pm 14.4^{\mathrm{a}}$ & $35.4 \pm 4.0^{\mathrm{a}}$ & $102.0 \pm 12.7^{\text {acd }}$ \\
\hline & ST3 & 11 & $11 / 0(0)^{\mathrm{a}}$ & $3 / 8(72.7)^{\mathrm{a}}$ & $89.25 \pm 16.2^{\mathrm{a}}$ & $35.25 \pm 5.1^{\mathrm{a}}$ & $120.0 \pm 14.2^{\text {ad }}$ \\
\hline & Mean & 35 & $30 / 5(14.3)^{\mathrm{A}}$ & $8 / 27(77.1)^{\mathrm{B}}$ & $73.3 \pm 9.0^{\mathrm{A}}$ & $34.4 \pm 2.3^{\mathrm{A}}$ & $102.9 \pm 8.2^{\mathrm{A}}$ \\
\hline \multirow{4}{*}{ 兒 } & LT1 & 12 & $6 / 6(50)^{\mathrm{bc}}$ & $0 / 12(100)^{\mathrm{a}}$ & $30.0 \pm 3.0^{b}$ & $39.5 \pm 2.7^{\mathrm{a}}$ & $63.5 \pm 3.0^{\mathrm{e}}$ \\
\hline & LT2 & 11 & $9 / 2(18.2)^{\mathrm{ac}}$ & $0 / 11(100)^{\mathrm{a}}$ & $38.18 \pm 4.7^{\mathrm{bc}}$ & $34.91 \pm 4.3^{\mathrm{a}}$ & $67.09 \pm 6.3^{\mathrm{e}}$ \\
\hline & LT3 & 10 & $8 / 2(20)^{a c}$ & $0 / 10(100)^{\mathrm{a}}$ & $31.8 \pm 3.6^{\mathrm{bc}}$ & $35.4 \pm 2.6^{\mathrm{a}}$ & $61.2 \pm 2.9^{\mathrm{e}}$ \\
\hline & Mean & 33 & $23 / 10(30.3)^{\mathrm{A}}$ & $0 / 33(100)^{\mathrm{A}}$ & $33.3 \pm 2.2^{\mathrm{B}}$ & $36.7 \pm 1.9^{\mathrm{A}}$ & $64 \pm 2.5^{\mathrm{B}}$ \\
\hline & Total mean & 68 & $53 / 15(22.1)$ & $8 / 60(88.2)$ & $51.30 \pm 4.9$ & $35.70 \pm 1.5$ & $81.5 \pm 4.6$ \\
\hline
\end{tabular}

Data were presented as mean \pm S.E.M.

a,b,c,d,e Different superscripts in the same column indicate significant differences among ST and LT groups $(P<0.05)$

$\mathrm{A}, \mathrm{B}$ Different superscripts in the same column indicate significant differences between ST mean and LT mean $(P<0.05)$

After artificial insemination, all ewes showing oestrus signs were naturally bred with previously proven fertile rams. A total of 11 ewes (3 ewes from ST1 and 2 ewes from ST2, ST3, LT1, and LT2) did not get pregnant after two natural breedings and they were considered to have infertility problems and excluded from the NRR and lambing rate data.

For the synchronization indicators and pregnancy rates there were no significant differences found between the ST and LT treatment groups, except for the oestrus response within $140 \mathrm{~h}$ and oestrus cessation $(P<0.05)$. The oestrus duration and oestrus cessation for ST groups ranged between 32.68 and $35.4 \mathrm{~h}$, and 88.7 and $120 \mathrm{~h}$, respectively, and for LT groups they ranged between 34.9 and $39.5 \mathrm{~h}$, and 61.2 and $67.09 \mathrm{~h}$, respectively. In the LT groups, the oestrus response was better synchronized than in the ST groups.

According to the application time of 300 IU PMSG, among all studied indicators of the ST subgroups, oestrus cessation of the ST1 was the shortest and differs only from ST3 $(P<$ $0.05)$. No statistical difference was observed among LT groups according to the application time of 300 IU PMSG among all studied variables. 
Table 2. NRR-30 and Lambing rate in ewes treated with 6 or 12-day intravaginal FGA sponge combined with PMSG

\begin{tabular}{|c|c|c|c|c|}
\hline \multicolumn{2}{|c|}{ Treatments } & \multicolumn{3}{|c|}{ Fertility results } \\
\hline & PMSG & $\mathrm{n}$ & NRR-30 (\%) & Lambing rate (\%) \\
\hline \multirow{4}{*}{ ST } & ST1 & 9 & $4 / 5(55.6)^{\mathrm{a}}$ & $5 / 4(44.4)^{\mathrm{a}}$ \\
\cline { 2 - 5 } & ST2 & 10 & $8 / 2(20.0)^{\mathrm{a}}$ & $8 / 2(20.0)^{\mathrm{a}}$ \\
\cline { 2 - 5 } & ST3 & 9 & $6 / 3(33.3)^{\mathrm{a}}$ & $6 / 3(33.3)^{\mathrm{a}}$ \\
\cline { 2 - 5 } & Mean & 28 & $18 / 10(35.7)^{\mathrm{A}}$ & $19 / 9(32.1)^{\mathrm{A}}$ \\
\hline \multirow{4}{*}{ LT } & LT1 & 10 & $7 / 3(30.0)^{\mathrm{a}}$ & $7 / 3(30.0)^{\mathrm{a}}$ \\
\cline { 2 - 5 } & LT2 & 9 & $7 / 2(22.2)^{\mathrm{a}}$ & $8 / 1(11.1)^{\mathrm{a}}$ \\
\cline { 2 - 5 } & LT3 & 10 & $6 / 4(40.0)^{\mathrm{a}}$ & $6 / 4(40.0)^{\mathrm{a}}$ \\
\cline { 2 - 5 } & Mean & 29 & $20 / 9(31.0)^{\mathrm{A}}$ & $21 / 8(28.6)^{\mathrm{A}}$ \\
\hline & Total mean & 57 & $38 / 19(33.3)$ & $40 / 17(29.8)$ \\
\hline
\end{tabular}

Data were presented as mean \pm S.E.M.

a,b,c,d,e Different superscripts in the same column indicate significant differences among ST and LT groups $(P<0.05)$

A,B Different superscripts in the same column indicate significant differences between ST mean and LT mean $(P<0.05)$

\section{Discussion}

This study showed that the length of the progestagen treatment affected oestrus response and oestrus cessation. The time of PMSG injection had no effect on the oestrus response and duration in either treatment group except for oestrus cessation in the short-term treatment. Synchronized ewes with progestagen showed oestrus between $24-84 \mathrm{~h}$ after sponge removal (Ungerfeld and Rubianes 1999a; Simonetti et al. 2000). In this study the oestrus occurred between $12-78 \mathrm{~h}$ in LT and $18-90 \mathrm{~h}$ in ST groups. More ewes showed oestrus at $18 \pm 6 \mathrm{~h}$ after sponge withdrawal in the LT (30\%) than ST (14\%).

In this study the time to the oestrus onset following the withdrawal of sponge in LT groups was found to be $33 \mathrm{~h}$, which was lower than $40 \mathrm{~h}$ found by Romano (1996), Ungerfeld and Rubianes (2002) and Emsen and Yaprak (2006), and similar to Freitas et al. (1996). The time to the oestrus onset in the ST group was found to be $73 \mathrm{~h}$; lower than the $84 \mathrm{~h}$ reported by Vinoles et al. (2001) and higher than the $46 \mathrm{~h}$ reported by Ungerfeld and Rubianes (2002) during non-breeding season.

Vinoles et al. (2001) reported that ewes treated with MAP for $6 \mathrm{~d}$ exhibited oestrus at 84 $\mathrm{h}$ and those treated for 12 days exhibited oestrus at $44 \mathrm{~h}$ after sponge removal. Also Zeleke et al. (2005) reported that the ewes treated with FGA for $14 \mathrm{~d}$ showed oestrus at $41 \mathrm{~h}$, which is later than the values obtained in the present study ( $\mathrm{ST}=73 \mathrm{~h}$ and LT $=33 \mathrm{~h})$.

The oestrus response within $140 \mathrm{~h}$ after sponge removal in LT groups (100\%) was significantly higher than in ST groups $(77 \% P<0.05)$. Although the results of LT groups were similar to those reported by others (Vinoles et al. 2001; Ataman et al. 2005), the results of ST groups were higher than those reported by Ataman et al. (2005).

The mean overall durations of the induced oestrus period were $34.4 \mathrm{~h}$ and $36.7 \mathrm{~h}$ for ST and LT groups respectively. The results of ST groups are longer than that reported by Dogan and Nur (2006). The results of LT groups are longer than those reported by Zeleke et al. (2005), shorter than reported by Evans et al. (2004) for LT used MAP in this breed. Oestrus cessation of ST (102 h) was significantly longer than that of LT ( $64 \mathrm{~h}, P<0.05)$. This finding was in agreement with data obtained by Zeleke et al. (2005) and Evans et al. (2004) for LT treated ewes with FGA or MAP.

To obtain a high success from cervically timed AI program when using synchronized breeding, it is essential to have a high oestrus response, ovulation rates and appropriate insemination time (Eppleston et al. 1991; Baril et al. 1993; Drion et al. 2001; Menchaca and Rubianes 2004). Prolonged progesterone treatment has a negative effect on oocyte 
development (Vinoles et al. 2001; Menchaca and Rubianes 2004). Menchaca and Rubianes (2004) reported that the long progesteron treatment results in subluteal progesterone level. This phenomenon leads to increasing the LH pulses frequency, but the LH surge does not occur, and result in persisting largest follicle (Vinoles et al. 1999). In the present study the NRR-30 and lambing rate varied between 20 and 55\%, and 11 and $44 \%$, respectively. Vinoles et al. (1999) obtained a higher pregnancy rate after short treatment ( 6 day of MAP) compared to the long treatment (12 day). During seasonal anoestrus the interval from sponge removal to the onset of oestrus was significantly shorter in progestagen treatment applied during 6 days than in 12-day treated ewes but in this case no CL was interfering with the terminal growing phase of the ovulatory follicle (Ungerfeld and Rubianes 1999b). These results were in agreement with our findings. The NRR-30 and lambing rate of the ST and LT after timed AI were $35.7 \%$ and $31.0 \%$ and $32.1 \%$ and $28.6 \%$, respectively, and there was no significant difference between groups.

To enhance the oestrus response and pregnancy rate after progestagen treatment during breeding season, luteal regression with a $\mathrm{PGF}_{2} \alpha$ injection should be ensured (Menchaca and Rubianes 2004). The declining fertility in the present study is probably due to delayed luteal regression in some cyclic ewes since no $\mathrm{PGF}_{2} \alpha$ was used. Previous studies (Baril et al. 1993; Greyling et al. 1997; Ungerfeld and Rubianes 1999a) demonstrated that pregnancy rates vary greatly $(20-80 \%)$ after different progestagen treatments following timed AI using fresh diluted semen or natural breeding. Also the lambing rate was highly dependent on the ewe breed (Ungerfeld and Rubianes 1999a; Emsen and Yaprak 2006), progestagen treatment protocols (Romano 1996; Vinoles et al. 2001; Dogan and Nur 2006), the breeding season (Ataman et al. 2005; Zeleke et al. 2005), the AI procedure (Eppleston et al. 1991; Baril et al. 1993; Menchaca and Rubianes 2004) and the AI time (Menchaca and Rubianes 2004). The decreased proportion of ewes lambing in the experiment may be explained by prolonged oestrus and delaying ovulation.

Different studies evaluated different dose levels of PMSG (Drion et al. 2001) and the timing of PMSG treatment (Eppleston et al. 1991; Zeleke et al. 2005). The PMSG has been shown to reduce the interval from sponge withdrawal to oestrus and improve the efficiency of synchronization of oestrus and ovulation during the breeding season. On the other hand, Baril et al. (1993) and Drion et al. (2001) reported that the use of PMSG has been associated with negative effects on pregnancy rates and appears immunogenic in ewes (Roy et al. 1999). In the present investigation, the administration of PMSG $24 \mathrm{~h}$ before sponge withdrawal resulted in an earlier oestrus response at $18 \pm 6 \mathrm{~h}$ in both ST (33\%) and LT $(50 \%)$ treatments. The time of PMSG injection did not yield a constant improvement in the oestrus response and duration in both ST and LT groups. However, it resulted in longer oestrus cessation period in ST groups than LT groups. Vinoles et al. (2001) reported that in short term treated ewes eCG provoked the development of follicular cysts. Therefore the reduction in fertility observed in ST groups could be associated with the development of follicular cysts.

The highest lambing rate was obtained in ST1 and LT3, these results were in agreement with the findings of Zeleke et al. (2005) but not with the findings of Eppleston et al. (1991).

In conclusion, the present study indicated that long-term progestagen treatment resulted in a higher synchronization than short-term progestagen treatment. The time of PMSG injection had no effect on the oestrus response and duration in either treatment groups except for the oestrus cessation in short-term treatment. Long and short-term progestagen treatments resulted in similar pregnancy rates; therefore, short progestagen treatments can be efficiently used as an alternative to long progestagen treatments. It might be useful to ensure luteal regression with a $\mathrm{PGF}_{2} \alpha$ injection to enhance the oestrus response and pregnancy rate after progestagen treatment during the breeding season. 


\section{Účinek dlouhodobého a krátkodobého ošetření progestagenem PMSG na synchronizaci říje a plodnost bahnic plemene Awassi během připouštěcí sezóny}

Synchronizace říje se využívá ke zvýšení plodnosti u mnoha druhů zvířat včetně ovcí. Cílem této studie bylo porovnat účinnost délky ošetření progestagenem (12 dní a 6 dní) na synchronizaci ř́ije (projev ř́ije, doba do nástupu říje a její délka) a reprodukční užitkovost. Ovcím byly aplikovány fluorogeston acetátové tampony (FGA), odnímané po různě dlouhé době a PMSG (sérový gonadotropin březích klisen). Bahnice $(\mathrm{n}=68)$ byly rozděleny do dvou skupin: dlouhodobě (LT, n = 33) a krátkodobě $(\mathrm{ST}, \mathrm{n}=35$ ) ošetřených fluorogeston acetátovými tampony (FGA). Zvírata z obou skupin byla ke konci doby intravaginální aplikace tamponu rozdělena do tří podskupin podle doby aplikace PMSG (300 IU). Sérový gonadotropin PMSG byl u LT1 a ST1 aplikován 24 hodin před vyjmutím tampónu, u LT2 a ST2 při vyjmutí tampónu a u LT3 a ST3 24 hodin po vyjmutí tampónu. Každá bahnice byla dvakrát intracervikálně inseminována 40 a 60 hod po odebrání tamponu, semenem rozpuštěným v odstředěném kravském mléce $\left(1000 \times 10^{6}\right.$ pohyblivých spermií v $\left.1 \mathrm{ml}\right)$. Poměr nezabřezlých (NRR-30) byl testován od 12. do 30. dne po odebrání tamponu zkušebními berany. Nástup a ukončení ř́ije byly u skupin ST a LT signifikantně rozdílné $(P<0,05)$. Synchronizace říje byla přesnější u skupiny LT oproti ST. Kromě ukončení říje už nebyly u ST podskupin $\mathrm{v}$ dalších studovaných ukazatelích žádné rozdíly. Ukončení estru bylo nejkratší u ST1 $(88,7 \pm 15,4$ h) a významně se lišilo od ST3 $(120,0 \pm 14,2$ h) $(P<0,05)$. Také mezi LT skupinami nebyly zaznamenány žádné rozdíly ve studovaných ukazatelech v závislosti na aplikaci PMSG $(P>0,05)$. NRR-30 a počty narozených jehňat a u skupin ST a LT byly po načasované umělé inseminaci $35,7 \%$ a $31,0 \%$, respektive $32,1 \%$ a $28,6 \%$ $(P>0,05)$.

\section{Acknowledgement}

The authors thank the Technical Manager of Ceva Sante Animale, Francois Deletang and the Scientific Director of Ceva-Dif A.Ş., Prof. Dr. Rauf Can for providing the progesterone sponges and PMSG.

\section{References}

ATAMAN MB, AKOZ M, AKMAN O 2005: Induction of synchronized oestrus in Akkaraman cross-breed ewes during and outside the breeding season: use of short-term and long-term progesterone treatments. Proceedings of the International $6^{\text {th }}$ Sheep Veterinary Congress, Crete, Greece, pp. 130-131

BARIL G, LEBOEUF B, SAUMANDE J 1993: Synchronization of estrus in goats: the relationship between time of occurrence of estrus and fertility following artificial insemination. Theriogenology 40: 621-628

DOGAN I, NUR Z 2006: Different estrous induction methods during the non-breeding season in Kivircik ewes. Vet Med-Czech 51: 133-138

DRION PV, FURTOSS V, BARIL G, MANFREDI E, BOUVIER F, POUGNARD JL, BERNELAS D, CAUGNON P, MCNAMARA EM, REMY B, SULON J, BECKERS JF, BODIN L, LEBOUF B 2001: Four years of induction/synchronization of estrus in dairy goats: effect on the evolution of eCG binding rate in relation with the parameters of reproduction. Reprod Nutr Develop 41: 401-412

EMSEN E, YAPRAK M 2006: Effect of controlled breeding on the fertility of Awassi and Red Karaman ewes and the performance of the off spring. Small Ruminant Res 66: 230-235

EPPLESTON J, EVANS G, ROBERTS EM 1991: Effect of time of PMSG and GnRH on the time of ovulation, LH secretion and reproductive performance after intrauterine insemination with frozen ram semen. Anim Reprod Sci 26: 227-237

EVANS ACO, DUFFY P, CROSBY TF, HAWKEN PAR, BOLAND MP, BEARD AP 2004: Effect of ram exposure at the end of progestagen treatment on estrus synchronisation and fertility during the breeding season in ewes. Anim Reprod Sci 84: 349-358

FREITAS VJF, BARIL G, SAUMANDE J 1996: Induction and synchronization of estrus in goats: the relative efficiency of one versus two fluorogestone acetate-impregnated vaginal sponges. Theriogenology 46: 1251-1256

GREYLING JPC, ERASMUS JA, TAYLOR GJ, VAN DER MERWE S 1997: Synchronization of estrus in sheep using progestagen and inseminating with chilled semen during the breeding season. Small Ruminant Res 26:137-143

MENCHACA A, RUBIANES E 2004: New treatments associated with timed artificial insemination in small ruminants. Reprod Fertil Develop 16: 403-413 
PEARCE DT, ROBINSON TJ 1985: Plasma progesterone concentrations, ovarian and endocrinological responses and sperm transport in ewes with synchronized oestrus. J Reprod Fertil 75: 49-62

ROMANO JE 1996: Comparison of fluorgestone and medroxyprogesterone intravaginal pessaries for estrus synchronization in dairy goats. Small Ruminant Res 22: 219-233

ROY F, COMBES B, VAIMAN D, CUIBIU EP, POBEL T, DELETANG F, COMBARNOUS Y, GUILLOU F, MAUREL MC 1999: Humoral immune response to equine chorionic gonadotropin in ewes: Association with major histocompatibility complex and interference with subsequent fertility. Biol Reprod 61: 209-218

SCARAMUZZI RJ, DOWNING JA, CAMPBELL BK, COGNIE Y 1988: Control of fertility and fecundity of sheep by means of hormonal manipulation. Austr J Biol Sci 41: 37-45

SIMONETTI L, BLANCO MR, GARDON JC 2000: Estrus synchronization in ewes treated with sponges impregnated with different doses of medroxyprogesterone acetate. Small Ruminant Res 38: 243-247

UNGERFELD R, RUBIANES E 1999a: Estrus response to the ram effect in Corriedale ewes primed with medroxy-progesterone during the breeding season. Small Ruminant Res 32: 89-91

UNGERFELD R, RUBIANES E 1999b: Effectiveness of short-term progestagen primings for the induction of fertile oestrus with eCG in ewes during late seasonal anoestrus. Anim Sci 68: 349-353

UNGERFELD R, RUBIANES E 2002: Short term primings with different progestagen intravaginal devices (MAP, FGA, and CIDR) for eCG-estrous induction in anestrus ewes. Small Ruminant Res 46: 63-66

VINOLES C, MEIKLE A, FORSBERG M, RUBIANES E 1999: The effect of subluteal levels of exogenous progesterone on follicular dynamics and endocrine patters during the early luteal phase of the ewe. Theriogenology 51: 1351-1361

VINOLES C, FORSBERG M, BANCHERO G, RUBIANES E 2001: Effect of long-term and short-term progestagen treatment on follicular development and pregnancy rate in cyclic ewes. Theriogenology 55: 993-1004

ZELEKE M, GREYLING JPC, SCHWALBACH LMJ, MULLER T, ERASMUS JA 2005: Effect of progestagen and PMSG on oestrous synchronization and fertility in Dorper ewes during the transition period. Small Ruminant Res 56: 47-53 